\title{
A Critical Look at a Blended English Language Teacher Education Program with an Emphasis on the Practicum
}

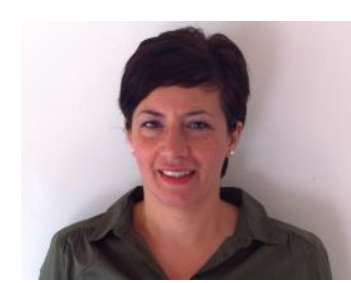

Ebru Melek Koç

Faculty of Education, Inonu University

* This present article is a much extended version of the conference paper: Koc, E.M. (2010).A Qualitative Study at Distance English Teacher Training Program: What are the problems of student teachers during Distance Field Experience? Proceeding of the International Educational Technology Conference (IETC). Boğaziçi University, Istanbul, Turkey.

\begin{abstract}
The aim of the present study was to explore what types of difficulties student teachers enrolled in a Bachelor of Arts (B.A.) in English Language Teacher Education program offered in a blended format and their cooperating teachers encountered during the student teacher practicum. The participants were 21 fourth grade student teachers and 12 cooperating teachers. Semi-structured interview questions were used to collect data. The interviews were tape-recorded and then transcribed to be analyzed. According to the findings, the problems student teachers faced were grouped into four areas: assessment systems, computer-assisted communication, challenges with mentors, and psychological issues. Cooperating teachers' problems were categorized as problems associated with the program and problems associated with the student teachers. The results of this study contribute to an increased understanding of the problems that student teachers and their cooperating teachers face during field experience at an English language teacher education program offered in a distance format. This study provides suggestions for establishing more effective mentorship during the field experience.
\end{abstract}

Keywords: English language teacher, distance education, practicum, student teachers, cooperating teachers

\section{Introduction}


Blended learning (BL), from a general aspect, is a combination of online learning and face-to-face learning. However, other definitions also exist. For example, Wu, Tennyson, and Hsia (2010) defines BL as "an instructional sytem that combines multiple learning delivery methods, including most often face-to-face classroom with asynchronous and/or syncrounous online learning" (p.155). In this definition online learning refers to technologically-supported learning activities, which are Web-based or available online. Graham (2006) considers BL as an approach, and defines BL as a learning approach that combines different delivery methods and styles of learning. The blend could be between any forms of instuctional technology (e.g., Videotype, Web-based learning, CD-ROM, etc.). Bliuc et al. (2007) regards BL as the set of "learning activities that involves a systematic combination of face-toface interactions and technologically-mediated interactions between students, teachers, and learning resources" (p. 234).

\section{Background to the Study}

In Turkey, English language teacher education programs are implemented in two formats. The first is a four-year traditional program. In this format, the student teachers receive face-to-face education, and the courses are term-based. Field experience is an important part of the English language teacher training program. In the present study, the terms field experience, school-based teaching, and practicum are used interchangeably. Regarding field experience, during their final year, the student teachers practice teaching at a cooperating school under the supervision of an experienced English language teacher (cooperating teacher) working at that school. The cooperating teacher and the university supervisor prepare a weekly schedule for each student teacher. The student teachers are required to go to the cooperating school at scheduled times each week, observe the cooperating teacher, create lesson plans, and practice teaching. The cooperating teacher is responsible for the professional development of the student teacher, including observing the student teacher and taking notes, providing assistance with the lesson plans, and giving feedback about the student teacher's work. The university supervisor is also responsible for the professional development of the student teacher. The university teacher's responsibilities are similar to those of the cooperating teacher: assisting the students with their lesson plans, observing them, and giving feedback about their teaching performance. The evaluation of the student teachers for this course is a shared responsibility of the cooperating teacher and the university supervisor.

The second program is designed for training English language teachers to meet the demands in Turkey. It is implemented in a blended format; that is, the student teachers receive face-to-face education in their first two years and take courses online in their third and fourth years. The main resource for the student teachers is the course books. To make these books more comprehensible, an online support program is offered to the student teachers. In this system, each unit of each course book is supported online by extra activities to be done during preparation, learning, and review, as well as a posttest that enables the student teachers to evaluate their own performance. Regarding the assessment of the student teachers, they can take the tests in any of 13 cities throughout Turkey. Student teachers who do not live in one of these cities have to take the tests in the nearest test center. For each course, they are required to take three tests throughout the two terms and a final test at the end of the second term. To assess the student teachers' teaching practice, the cooperating teachers are required to evaluate the work of the student teachers at intervals, complete observation and evaluative forms, and send their portfolio to the course evaluator committee at the end of the term. Fifty percent of the student teacher's final grade comes from the cooperating teacher and $50 \%$ comes from the evaluator committee's evaluation. 
Regarding field experience, the student teachers in the blended program, unlike in the traditional program, are supervised regularly only by their cooperating teachers. Although the university supervisors in this program cannot make regular visits to the cooperating schools, an expert group visits the schools once or twice a year to provide onsite support related to the practicum process. In addition, a team of teachers evaluates the student teacher's lesson plans at the end of each term and gives feedback through letters to both the cooperating teacher and the student teacher by making suggestions on how to improve the process of writing and evaluating lesson plans. The cooperating teachers are also provided with handbooks prepared by the faculty and CDs to guide them during the teaching practice course. These resources include guidelines about the responsibilities of the practicum's members, model lesson plans and observation or evaluation forms. Because the cooperating teachers do not have the opportunity to interact with a university supervisor regularly, the most frequently used resources are the handbook and the CD.

It is largely the cooperating teacher's responsibility to supervise the student teachers during the practicum. In other words, cooperating teachers have to take on more responsibilities because they are readily available for the student teachers to contact during their practicum. However, online support (asynchronous environment) is offered to student teachers, and they can at any time ask about problems related to the field experience period via Email. In addition to Email, the student teachers and cooperating teachers also communicate with university supervisors by telephone and mail.

Field experience is considered to be the most important part of a teacher education program (DarlingHammond \& Youngs, 2002; Guyton \& McIntyre, 1990). Quality in teacher preparation largely depends on the quality of the field-based experience (Endeley, 2014; O'Shea, Hammite, Mainzer, \& Crutchfield, 2000). However, there is little research on field experience in distance education programs (Conderman, Morin, \& Stephens, 2005). The most challenging part of a distance teacher education program is the field experience (Savaş, 2006). Recent research indicate that logistical and educational challenges may occur in distance teacher education contexts (Du Plessis, 2013, 2011) and identification of the weaknesses and challenges of a program is a vital step in ensuring improvements of its effectiveness (Scrieven,1998). Therefore, a diagnosis of the challenges that the student teachers and cooperating teachers encounter will provide a holistic view of the program and feedback to the program organizers of the blended teacher education programme on monitoring the supervisory process and will enable them to take steps to minimize the impact of these challenges, which in turn could serve as a basis for the improvement of the programme. Based on these targeted outcomes, the research questions of the present study are:

1. What problems do student teachers in the blended English language teacher education face during their field experience?

2. What problems do cooperating teachers supervising the student teachers in the blended English language teacher education face during the distance field experience?

\section{Theoretical Framework}

Two conceptualizations frame the study. The first one is the equivalency theory. A central key to this theory is the concept of equivalency, which refers to designing learning environments in such a way as to provide equal value for on-campus and distance learners. In other words, although the oncampus and distance learners have fundamentally different learning environments, equivalent learning experiences should be designed for all students regardless of their distance from the 
institution (Simonson, 1999; Scholosser \& Simonson, 2006). Another key to equivalency theory is the use of telecommunication technology, such as synchronous audio, video, and computer networks, to promote communication (Simonson, 1999). Synchronous interaction need not be mandatory, however. Various communications systems, including asynchronous ones, can and should be used for distance education, as long as the goal of equivalency of experiences is met.

The second theory framing the present study is social constructivism, which claims that development must occur through social interactions (Vygotsky, 1978). This is true of the student teaching practice. The student teacher adds new skills and information to his or her existing mental framework through interactions with his or her environment during the field experience. For Vygotsky (1978), the teacher (mentor) is a facilitator and guide.

Cooperating teachers are facilitators who assist student teachers as they attempt to construct their own learning and meaning. When the learner needs the greatest assistance, the cooperating teacher provides scaffolding to ensure that the learner's constructs will continue to grow stronger and more complex. The mentor also provides scaffolding and encouragement to build the student's confidence.

\section{Research Methodology}

\section{Participants}

There are two groups of participants. Participants in the study were 21 fourth year student teachers doing their field experience in four regions of Turkey (Marmara, Aegean, Central Anatolia, and East Anatolia).

In the present study, the student teachers were in their final year. All the student teachers were assigned to a cooperating school in the city where they resided to practice teaching for five hours a week under the supervision of a cooperating teacher at that school. In addition to this course, they also took other courses such as Using English Literature in Teaching, Testing and Evaluation in English, Teaching Language Skills, Pedagogical Grammar, Language Acquisition, Turkish Phonology, and Morphology and Syntax.

The second group of study participants comprised 12 English teachers who were assigned as cooperating teachers to supervise the student teachers during the practicum. Each cooperating teacher supervised between four and seven student teachers.

\section{Data Collection Tool}

Data were collected through semi-open interview questions based on the related literature (Du Plessis, 2013; Faikhamta, Jantarakantee, \& Roadrangka, 2011) which asked about the challenges and problems they encountered during the practicum period. They were also asked to give examples of these challenges. Two experts from the English Language Teaching (ELT) department were asked to review the semi-open interview questions for achieving content and face validity.

\section{Data Collection Procedures}

By the time the data were collected, the student teachers and the cooperating teachers had been in the practicum for nearly two months. After preparing an interview schedule, the researcher constructed the interview protocols with the study participants. The researcher traveled to three cities (Bursa, Eskişehir, and Malatya) to construct the interview protocols with the participants in person. An 
informed consent form was prepared according to the European Commission Ethical Research Guidelines for the volunteer participants before the collection of the data through interviews. The participants were informed about the research in detail. The interviews were conducted in Turkish and recorded. Interview sections lasted approximately 20 minutes. The interviews took place at the student teachers' schools during the school day. A set of semi-structured interview questions such as "What are the problems you faced during practicum?" and "What are the problems related to your cooperating teacher?" served as the main data collection instrument.

\section{Data Analysis}

The interview sections were tape-recorded and then transcribed. The written data were analyzed through qualitative analysis (Walker, 2002). First, the student teachers were numbered and labeled as ST 1, ST 2, and so on. A similar process was applied for the cooperating teachers. At the beginning of the analysis, the quotations were examined line by line. Meaningful responses, which could be either a single sentence or a cluster of sentences, were identified. Responses with meanings similar in content were clustered and categorized. Then, the responses were reread with a focus on key words. Each key word was underlined. During a third round of reading, responses with similar key words were highlighted in color, with each color representing a particular group of key words. This helped the researcher categorize and cluster related responses. Lastly, each categorized quotation was analyzed again, and themes that turned out to be subsumable under others were identified as sub-issues. The sample student teacher and cooperating teacher responses were translated from Turkish to English.

\section{Results}

The analysis of the results indicated three types of problems: problems common to both the student teachers and their cooperating teachers, problems reported by only student teachers, and problems reported by only cooperating teachers (Table 1). In this section, the results will be discussed according to these three types of problems.

Table 1

Problems of Problems of Student Teachers (STs) and Cooperating Teachers (CTs) During Field Experience

\begin{tabular}{llll}
\hline $\begin{array}{l}\text { Problems Common to Both } \\
\text { CTs and STs }\end{array}$ & Problems of STs & \multicolumn{1}{c}{ Problems of CTs } \\
\hline$\bullet \quad$ lack of faculty & $\bullet$ assessment & $\bullet$ & heavy paper workload \\
& support & $\bullet$ CMC & - student teachers not fulfilling \\
& $\bullet$ isolation & their responsibilities \\
& & & irregular attandence of STs \\
\hline
\end{tabular}

\section{Problems Common to Both the Student Teachers and Their Cooperating Teachers}

Lack of faculty support. The cooperating teachers revealed that they were not very sure about the practicum process, which included issues such as the responsibilities of the cooperating teachers and student teachers, lesson planning, and evaluation of the student teachers. The only resource available when a problem was identified is the handbook prepared by the faculty. A cooperating teacher mentions the following: 
Some of the points are difficult to understand....we ask one another about these unclear points and discuss them. We do not have the opportunity to clarify everything. Although the faculty says we can contact them whenever we have a question, there are times when we are unable to reach them.

The cooperating teachers indicated their need to interact more often with the university instructors responsible for the program. One of the cooperating teachers explained this problem as follows:

The only resource during this period is the handbook prepared by the university. We, together with the other cooperating teachers at the school, read the information and then meet our responsibilities accordingly. If there is something unclear about this information, we have the chance to contact the faculty by Email and phone. However, this is not very practical and takes time. So, we try to find the right way through discussions.

In the same vein, one of the student teachers mentioned a need for orientation:

With the cooperating teacher, together we tried hard to understand the [practicum] process for a month. I suggest that a committee should be sent to each school by the faculty at the beginning of the year in order to give information to the students and the cooperating teachers about the field experience process. This is very necessary.

Similarly, a cooperating teacher highlighted a need for an orientation program to minimize the identified problems:

In our school only one cooperating teacher was invited to the orientation meeting. If all the cooperating teachers had been invited to that meeting, we could have understood the process clearly and therefore may not have experienced such problems.

A lack of a regular university supervisor was identified as problem by the student teachers. One student teacher noted the need for more university support:

I wish I had a supervisor from the university to consult regarding any issue about teaching. I come to the school only on Tuesdays. Therefore, if I have a problem I have to wait until Tuesday to get help from my cooperating teacher. Aside from field experience, I have faced problems related to other courses. If there were a university supervisor, I would ask for assistance not only for the field experience but also for other courses. What is more, a second pair of eyes on my work would help me a lot.

Similarly, another student teacher stated:

The supervision by only a cooperating teacher is not sufficient. It would be superb to have a university supervisor with an MA. in the field. Also, I wish I had a university supervisor who is an assistant professor or an associate professor.

\section{Problems Reported by Only Student Teachers}

The qualitative analysis revealed three main themes regarding the problems of the student teachers: (a) assessment, (b) computer-mediated communication (CMC), and (c) a feeling of isolation. Themes 
and issues recognized within these themes are supported by the student teacher responses in the following section.

Assessment. In the blended program, student teachers are required to attain a mark of 70 or above to pass a course, which most of the student teachers find very difficult to achieve. Therefore, they regard the assessment system as very strict and identify it as the cause of a low percentage of graduates. One of the student teachers commented on this as follows:

To pass a course you must get 70 . If you get a cumulative average of 69 , you fail. Because of just 1 mark you have to take the course again, which means to repeat the class. I have a lot of friends who repeated their classes once or more. Out of 52 student teachers only 2 of them achieved to graduate in four years. The rest had to repeat their classes due to this strict grading system. That is why the first graduates (of the blended programme) were very few.

Student teachers also think that such a strict assessment system negatively affects their psychology and is their most important source of their stress. One of the student teachers report his feelings as follows:

What tires us is not the field experience, but this grim assessment system. The institute has to find a solution to this. I understand that quality is important. But quality can not be achieved by putting all the student teachers under such a great pressure.

Computer-mediated communication (CMC). Course books are the main resources for the distance student teachers in the blended program. An online support system was designed to help the student teachers understand the course books better. It also provided the student teachers a tool with which to communicate with the course instructor and their peers to receive instructional support. However, some of the student teachers mentioned that not all the student teachers have a computer in their home or access to the Internet, which could compromise the equivalency in distance learning. One student teacher stated her concern in the following quotation:

I often used the online support system, since I have a computer and internet at home. Therefore, I was successful at the courses and passed the $4^{\text {th }}$ class. But I had friends who did not have a personal computer and internet access, which means a big shortcoming. From that point of view I find myself lucky. But what about the others who do not have the same opportunity as I have? They are likely to fail and prolong the graduation.

Another problem related to the online support was the timeliness of feedback. A student teacher commented on this:

For the $4^{\text {th }}$-year students who are doing their field experience, there is a discussion board on the website. If there is something we do not understand about the course, we can e-mail a question. However, the feedback is always late. I waited for months for an answer.

A feeling of isolation. A feeling of isolation was another cited problem. Many of the student teachers reported that they would like to meet the instructors of the courses they take online. One of the student teachers states his desire as follows: 
The institute could organize orientation meetings for the student teachers which offered the opportunity to meet all the course instructors whom we know only from the distance. If we met the course instructors, this could encourage us to begin the university willingly. We only meet the staff at the Open faculty office administrator in the city of where the student teacher accommodates and the instructors of the courses during the face to face training. It is interesting that I do not know my university. My friend asks me about the university and Eskisehir. But, I cannot tell anything since I know nothing about it.

\section{Problems Reported by Only Cooperating Teachers}

According to the analysis, cooperating teachers' problems fall into two main categories: problems associated with the program and problems associated with the student teachers. A further analysis of these themes was conducted that resulted in sub-categories. These themes are indicated in the following:

Heavy paper workload. Some of the cooperating teachers were not satisfied with the amount of paper work required by the evaluation process. A cooperating teacher commented on that process:

The evaluation procedure is too much. I believe that instead of completing an observation form for each student teacher observation, giving general feedback with regard to the strong and weak aspects of the student teacher performance and filling out only one evaluation form (for each student teacher) at the end of the term would be much better.

Another cooperating teacher commented:

Both observation forms and evaluation forms have a lot of items. It is very difficult to read and respond to all these items objectively for each lesson a student teaches, since I have difficulty remembering all these items. These forms should be minimized.

Most of the cooperating teachers suggested taking notes rather than using the forms:

I think a common problem for cooperating teachers is to complete the observation and evaluation forms for each student for every lesson he/she teaches. Instead of the forms, I think taking detailed notes about the weak and strong points of their teaching would be better. That is what I do, and at the end of the year I complete the forms based my notes.

Student teachers not fulfilling their responsibilities. One of the cooperating teachers indicated that the student teachers did not fulfill their responsibilities, and they were very irresponsible with materials. She commented:

I give my students a copy of my daily and yearly lesson plans and ask them to prepare their plans accordingly. My students lost my original plans.

Another cooperating teacher commented:

At our school there are a variety of resources such as TV and CDs to be used in language teaching. However, the student teachers do not use these resources and are not adequately prepared for their teaching performance. For example, before a lesson the student teacher 
should prepare some comprehension questions about the reading text that will be the focus of the lesson, but he/she does not.

One of the cooperating teachers explained that the heavy course program might lead to such irresponsibility. He commented:

Their lesson plans are not of high quality. This could be due to their heavy course load. They have to work hard to achieve a 70 to pass each course. Therefore, they cannot study for their courses and at the same time create good lesson plans.

Irregular attendance of the student teachers at the cooperating school. All student teachers are expected to attend the cooperating school for five hours per week. Unless the student teacher obtains permission, he or she may not take the day off. Interviews with the cooperating teachers revealed that the cooperating teachers are not satisfied with their student teachers' attendance habits.

One of the male cooperating teachers claimed that university support was essential for evaluating student teachers and likely would help student teachers take the process more seriously. She commented as follows:

The students do not attend the cooperating school regularly; they use any excuse for an absence...they do not enjoy coming here....However, the student teachers in the traditional program attend regularly....It would be better if the student teacher's attendance were monitored by somebody other than the cooperating teacher. This would help the student teacher to take his/her study more seriously.

Similarly, another female cooperating teacher mentioned her concern about the student teachers' absences at the cooperating school:

At the beginning of the practicum, the student teachers attend regularly. However, after some time, absences begin. Most of the students use their course exams as an excuse for not attending the cooperating school.

\section{Discussion}

A striking finding of the study is that lack of support by the faculty was indicated to be a problem by both student teachers and cooperating teachers. Research also supports that lack of collaboration may lead to cooperating teachers to encounter supervisory problems (Young \& MacPhail, 2014).

Both groups highlighted a need for an orientation meeting. One explanation for this finding could be found in Ramanathan and Wilkins-Canter (2000). They found that most cooperating teachers received no specific training on supervision techniques. Therefore, the cooperating teachers did not feel adequately prepared to be effective supervisors. Likewise, less than half of the mentors in Cornell's study (2003) indicated that the cooperating teachers received adequate training as supervisors. The blended English language teacher education program provides an orientation to only those cooperating teachers who are group leaders at their school. The student teachers and the rest of the cooperating teachers assigned to supervise these students are not provided such an orientation. They 
rely on the handbook and a CD about the practicum process prepared by the faculty for the necessary information for an effective mentorship.

The cooperating teachers also highlighted the need for regular support for the problems they face throughout the year. Similarly, student teachers mentioned their need for supervision by a university instructor as a second supervisor. Many studies provide evidence that university supervisors contribute to a successful experience for student teachers and cooperating teachers (Griffin et al., 1983; Koehler 1984; Zimpher, de Vas, \& Nott, 1980). Applegate and Lasley (1984) revealed that one of the concerns of cooperating teachers was for the need for university supervisors to provide guidance and direction to both the student teacher and the cooperating teacher.

The university supervisor also acts as a bridge between the faculty, the cooperating school, and the cooperating teacher. Without a university supervisor, communication among these groups is likely to suffer. A lack of regular supervision by a university supervisor may also endanger the quality of the cooperating teacher's supervision (Young \& MacPhail, 2014) since cooperating teachers are not donated with the expectations and purpose of field experience (Anderson, 1993).

This problem can be discussed in relation to social constructivitism, which claims that learning occurs through interaction. Throughout the field experience period, the student teachers, cooperating teachers, and university supervisors are in close contact. The student teachers and the cooperating teachers have the opportunity for face-to-face interaction with the university supervisor for academicor process-related problems. The student teachers in the traditional English language education program are supervised by both their university supervisors and their cooperating teachers at the school where they teach; their lesson plans are corrected, they receive oral or written feedback on their teaching practices, and so on. For student teachers, such interaction and constructive feedback provides a valuable experience for the student teachers to construct their own knowledge for learning (Faikhamta et al., 2011). However, a regular support of the university supervisors in the blended program is not accessible to the student teachers and their cooperating teachers in person, though they can share their problems and receive guidance from the university supervisor via mail, Email, or phone. Cochran-Smith (1991) mentions that pairing a student teacher with a single cooperating teacher fails to prepare the student teacher, as it limits him or her to learning from just one mentor and such one-folded support is not effective and does not cover learner needs (Tenenbaum, Naidu, Jegede, \& Austin, 2001). In such a social context, where the collaboration and interaction is limited, student teachers unfortunately have limited opportunities to reflect on their beliefs, strenghts, and weaknesses of their own teaching.

The lack of regular support from a university supervisor also compromises the equivalency theory, which states "the more equivalent the learning experiences of distance students are to that local students, the more equivalent will be the outcomes of the learning experiences" (Simonson, 1999, p.7).

The first problem identified by student teachers was related to the assessment. According to the grading system, the cumulative average score of these tests must be 70 for a student to pass a course. If the student teacher gets a grade below 70, he or she has to retake the course next year. The student teachers reported that the grading system was very strict.

The use of CMC comprises a vital part of the blended English teacher training program. However, the student teachers in this study reported that not all of the student teachers have the opportunity to use 
CMC, which can be a threat to having equal learning opportunities. Similarly, related literature indicates acess to ICT (Forbes \& Khoo, 2015), computer, and Internet (Ukpo, 2005) is limited in distance programs. This conflicts with the framework of distance learning, which emphasizes that "the distance education systems should strive to provide equal learning experiences for all students" (Simonson \& Schlosser, 1995, p.71). Similarly, Simonson (1999) states that "various communications systems, including asynchronous ones, can and should be used for distance education, as long as the goal of equivalency of experiences is met" (p.7). Another problem related to CMC indicated by the student teachers was the delay in feedback from the course instructor. A similar finding was mentioned by Savaş (2006), who found that in asynchronous communication there is a time lapse between sent and received messages. Regarding the inefficiency of asynchronous mode of communication, Offir, Lev, and Bezalel (2008) claim that rather than the synchronous mode of communication is preferred by students who are georaphicaly isolated since the asynchronous mode of communication causes poor quality interaction, which in turn minimize learning (Kannan \& Narayanan, 2015; Norburg, 2012). Another problem reported by the student teachers was that they felt isolated. In the same vein, Kirkup and Jones (1996) mention that isolation and individualization of the student is one of the most significant weaknesses of distance education. Similarly, in Ngoepe's (2014) study the student teachers valued interpersonal interaction as a key quality and indicated it to be lacking. The primary role of $\mathrm{CMC}$ in the blended program is to help the student teachers enhance their understanding of the course content and to establish a rapport with their peers and course instructors. Such communication and interaction reduce student teachers' feeling of isolation and make them believe that they belong to a part of a social community (Bloomfield, 2000).

According to the results, one of the biggest concerns of the cooperating teachers was that student teachers do not seem to take full responsibility during the practicum. Observing the cooperating teacher, making lesson plans, and practicing teaching in a real classroom are the main responsibilities of student teachers during their field experience. Lesson plans constitute an integral part of the student teachers' evaluation and assessment process. Before sending the student teacher's portfolio to the course evaluator committee at the Open Faculty to be graded, the cooperating teacher is required to grade the student's portfolio, which consists of reflective journals, lesson plans, and observation and evaluation forms. Lesson plans comprise $40 \%$ of the total assessment. Therefore, to write good lesson plans and to achieve higher grades, the student teachers may ask their cooperating teachers for more help when preparing their lesson plans.

Another problem mentioned by the cooperating teachers was that the student teachers did not regularly attend the cooperating school. Student teachers are required to attend five hours per week, during which they observe their cooperating teachers and peers and practice teaching themselves. Most of the cooperating teachers highlighted the need for university faculty to assist in monitoring student teachers' attendance. Snowden and Daniel (1988) state that "distance education systems, because of the inherent complexity and interdependence of their parts require 'tighter' management than conventional educational institutions" (p. 339). This belief is echoed by Rumble (1992), who states that the key to successful management of distance education lies in planning, organization, leadership, and control (p. 31).

\section{Conclusion}

The present study aimed to explore the problems of both student teachers and their cooperating teachers in the blended English language education program in relation to the field experience. This 
study is important in that it has provided the student teachers with an opportunity to voice their problems. Though the number of case study participants is limited, the findings shed light on the types of problems that student teachers encounter during their field experience. Cooperating teachers have significant influence on the quality of the student teaching experience (Glickman \& Bey, 1990; Ngoepe, 2014). Therefore, it was also important to investigate the problems they face during the field experience to improve the supervising process. To improve the quality of the practicum period and mentoring, more guidance for the cooperating teachers is needed. Tjeerdsma (1998) suggested that cooperating teachers need to be trained in the techniques and methods of quality supervision if they are to function as effective supervisors. Because the value of the teaching practice experience in the cooperating schools seems to depend on the quality of the cooperating teachers, organizers of the blended English language teacher education program should pay more attention to the selection of cooperating teachers. Along the same lines, Sampong (2007) claims that distance pre-service teacher education is executed efficiently when the practicum component is planned properly and is well supervised by qualified master teachers. Therefore, cooperating teachers should be selected based on specific criteria. If the selection of cooperating teachers focuses on traits that are known to be effective, it is likely to increase the quality of the cooperating school placements and ultimately the quality of the field experience.

Robinson (1997) outlined the problem and stated that stability of quality in the practicum is very difficult for students spread over a large geographic area. It is challenging to understand cooperating school conditions from a centralized point of control. Therefore, further studies are needed to build on the information provided by the present study. For example, CMC is a vital part of the blended program and has two functions. The informative function enables the student teachers to better understand the content of the courses. CMC offers the student teachers access to supportive information and increases opportunities for them to exchange ideas, ask questions, and receive feedback. Through the use of Email and discussion boards, student teachers communicate with their peers and their course experts about their experiences during school-based teaching, which addresses the socialization aspect of the CMC. Further research with a qualitative analysis of these communications would be valuable, as such information could shed light on the types of problems student teachers face during their field experience and whether CMC helps in the socialization of student teachers. Related to the use of CMC, student teachers also reported that they face problems such as delayed feedback. Therefore, another suggestion for further research is a study focusing on the student teachers' and cooperating teachers' evaluations of CMC.

The present study will be significant to teacher education programs offered in distance or blended formats. Successful program development occurs because of evaluation. Therefore, the problems identified in the present study should be regarded as constructive feedback by the program and used for the implementation of new programs.

The results of this study contribute to an increased understanding of the problems that student teachers and their cooperating teachers face during field experience at an English language teacher education program offered in a distance format. This study provides suggestions for establishing more effective mentorship during the field experience in relation to student teachers' socialization. Kirkup and Jones (1996) summarize the most significant weaknesses of distance education as (a) its inability to offer dialogue in the way that conventional face-to-face education does, (b) the inflexibility of its content and study method, and (c) the isolation and individuality of the student. Therefore, cooperating teachers who mentor student teachers in distance-learning teacher education programs 
should be aware of the importance of socialization and should implement orientation meetings for student teachers.

Establishing a closer link between teacher educators and cooperating schools improves teacher quality (Metcalf-Turner \& Fischetti, 1996; Johnson, 2003). The quality of the student teaching experience is extremely important and depends on strong collaboration by its members (Darden, Scott, Darden, \& Westfall, 2001; Koç, 2012; Koç, 2011; Zulu, 2015). Cooperating teachers need to be supported by the university to perform their roles as mentors effectively. A stronger partnership needs to emerge between the university and the cooperating schools to increase communication and provide a more beneficial experience for the student teachers.

\section{References}

Anderson, N. A. (1993). Problems encountered in an early field experience, Education, 113(4), 606-614

Applegate, J., \& Lasley, T. (1984). Cooperating teachers' problems with preservice field experience students. Journal of Teacher Education, 33(2), 15-18.

Bliuc, A.-M., Goodyear P., \& Ellis, R.A., (2007). Research focus and methodological choices in studies into students' experiences of blended learning in higher education. Internet and Higher Education, 10, 231-244. doi:10.1016/j.iheduc.2007.08.001

Bloomfield, D. (2000). Voices on the web: Student teachers negotiating identity. Asia-Pacific Journal of Teacher Education, 28(3), 199-217. DOI: 10.1080/713650696

Cochran-Smith, M. (1991). Learning to teach against the grain. Harvard Educational Review, 61(3), 279-310.

Conderman, G., Morin, J., \& Stephens, J. T. (2005). Special education student teaching practices. Preventing School Failure, 49(3), 5-10.

Cornell, C. (2003). How mentor teacher perceive their roles and relationships in a field-based teachertraining program. Education, 124(2), 401-411.

Darden, G., Scott, K., Darden, A., \& Westfall, S. (2001). The student-teaching experience. Journal of Physical Education, Recreation and Dance, 72(4), 50-53.

Darling-Hammond, L., \& Youngs, P. (2002). Defining highly qualified teachers: What does scientifically-based research actually tell us? Educational Researcher, 3(9), 13-25.

Du Plessis, E. C. (2011). A mixed method study about the experiences of students and lecturers of work-integrated learning in teacher education. International Journal for e-Learning Security, 1(1/2), 60-70. DOI: 10.20533/ijds.2046.4568.2011.0008

Du Plessis, E.C. (2013). Mentorship challenges in the teaching practice of distance learning students. The Independent Journal of Teaching and Learning, 8, 29-43. Retrieved from http://www.iie.ac.za/Documents/TheJournalVol82013.pdf 
Endeley, M. N. (2014). Teaching practice in Cameroon: The effectiveness of the University of Buea model and implications for quality. Australian Journal of Teacher Education, 39(11), 147160. Doi: 10.14221/ajte.2014v39n11.9

Faikhamta, C., Jantarakantee, E., \& Roadrangka, V. (2011). The current situation of field experience in a five-year science teacher education program in Thailand. US-China Education Review, B(6), 829-839.

Forbes, D., \& Khoo, E. (2015) Voice over distance: A case of podcasting for learning in online teacher education. Distance Education, 36(3), 335-350. doi: 10.1080/01587919.2015.1084074

Glickman, C., \& Bey, T. (1990). Supervision. In W. R. Houston (Ed.), Handbook of research on teacher education (pp. 549-566). New York, NY: Macmillan.

Graham, B. (2006). Conditions for successful field experiences: Perceptions of cooperating teachers. Teaching and Teacher Education, 22(8), 1118 - 1129. doi:10.1016/j.tate.2006.07.007

Griffin, G., Barnes, S., Hughs, S., O'Neal, S., Defino, M., Edwards, S., \& Huckill, H. (1983). Clinical preservice teachers' education: Final report of a descriptive study. Austin, TX: Research and Development Center for Teacher Education, The University of Texas at Austin.

Guyton, E., \& McIntyre, D. J. (1990). Student teaching and school experiences. In W. R. Houston (Ed.), Handbook of research on teacher education (pp. 514-537). NewYork, NY: Macmillan.

Johnson, J. L. (2003). Distance education: The complete guide to design, delivery, and implement. New York, NY: Teachers College Press.

Offir, B., Lev, Y., \& Bezalel, R. (2008). Surface and deep learning processes in distance education: Synchronous versus asynchronous systems. Computers and Education, 51(3), 1172-1183. doi: 10.1016/j.compedu.2007.10.009

O'Shea, D., Hammite, D., Mainzer, R., \& Crutchfield, M. (2000). From teacher preparation to continuing professional development. Teacher Education and Special Education, 23(2), 7177. doi:10.1177/088840640002300202

Kannan, K., \& Narayanan, K. (2015). A structural equation modelling approach for massive blended synchronous teacher training.Journal of Educational Technology \& Society, 18(3), 1-15. Retrieved from http://www.jstor.org/stable/jeductechsoci.18.3.1

Kirkup, G., \& Jones, A. (1996). New technologies for open learning: The superhighway to the learning society? In P. Raggatt, R. Edwards, \& N. Small (Eds.), Adult learners, education and training 2: The learning society-challenges and trends (pp. 272-291). London, UK: Routledge.

Koç, E. M. (2012). Idiographic roles of cooperating teachers as mentors at initial distance teacher education. Teaching and Teacher Education, 28(6), 818-826. doi: 10.1016/j.tate.2012.03.007.

Koç, E.M. (2011): Development of mentor teacher role inventory. European Journal of Teacher Education, 34(2), 193-208 doi: 10.1080/02619768.2010.539199 
Koehler, V. (1984). University supervision of student teaching. Paper presented at the annual meeting of the American Educational Research Association, New Orleans (ERIC Document Reproduction Service No. ED 245 105).

Metcalf-Turner, P., \& Fischetti, J. (1996). Professional development schools: Persisting questions and lessons learned. Journal of Teacher Education, 47(4), 292-299. DOI: 10.1177/0022487196474007

Ngoepe M. G. (2014). An examination of some instructional practices in selected rural secondary schools. Mediterranean Journal of Social Sciences, 5(9), 464-469. DOI: 10.5901/mjss.2014.v5n9464

Norburg, A. (2012). Blended learning and new education logistics in northern Sweden. In D. Oblinger (Ed.), Game changers: Education and information technologies (pp. 327-330). Boulder, CO: Educause.

Ramanathan, H., \& Wilkins-Canter, E. (2000). Preparation of cooperating teachers as evaluators in early field experiences. Action in Teacher Education, 22(1), 101-111.

DOI:10.1080/01626620.2000.10462997

Robinson, B. (1997). Distance education for primary teacher training in developing countries: Innovations in delivering primary education. London, UK: Cassell Educational Press.

Rumble, G. (1992). The competitive vulnerability of distance teaching universities. Open Learning, 7(2), 31-45. Retrieved from http://www.c3l.uni-oldenburg.de/cde/econ/readings/rumbleg2.pdf

Sampong, K. (2007). An evaluative study of distance teacher education program in a university in Ghana (Unpublished doctoral dissertation). Oral Roberts University, Tulsa.

Savaş, P. (2006). A case study of faculty support in the distance English language teacher education program at Anadolu University (Unpublished doctoral dissertation). University of Florida, Florida.

Schlosser, L. A., \& Simonson, M. R. (2006). Distance education: Definition and glossary of terms (2nd ed.). Greenwich, CT: IAP.

Simonson, M. (1999). Equivalence theory and distance education. TechTrends, 43(5), 5-8. Retrieved from http://link.springer.com/article/10.1007/BFo2818157

Snowden, B. L., \& Daniel, J. S. (1988). The economics and management of small postsecondary distance education systems. In D. Sewart, D. Keegan, \& B. Holmberg (Eds.), Distance education: International perspectives (pp. 398-424). New York, NY: Routledge.

Simonson, M., \& C. Schlosser. (1995). More than fiber: Distance education in Iowa. Tech Trends, 4O(5), 13-15. Retrieved from http://link.springer.com/article/10.1007/BFo2818826

Tenenbaum, G., Naidu, S., Jegede, O., and Austin, J. (2001). Constructivist pedagogy in conventional on-campus and distance learning practice: an exploratory investigation. Learning and 
Instruction, 11, 87-111. Retrieved from

http://kodu.ut.ee/ triinm/educational technology2/artikkel1.pdf

Tjeerdsma, B. J. (1998). Cooperating teachers perceptions of and experiences in the student teaching practicum. Journal of Teaching in Physical Education, 17, 214-230.

Ukpo, E. (2005). Towards excellence in student services at the National Teachers' Institute Nigeria. In A. Gaskell, \& A. Tait, (Eds), The Procceding book of the $1^{\text {th }}$ Cambridge International Conference on Open and Distance Learning (pp: 200-209). Retrieved from http://www.vhi.st-edmunds.cam.ac.uk/events/past-events/CDE-conference/CDEPapers/2005-1-cde

Vygotsky, L. S. (1978). Mind and Society. Cambridge, UK: Howard University Press.

Walker, C. A. (2002). Bridging the distance: Response to preservice teacher postings on a literacy and technology electronic mailing list. Journal of Research on Technology in Education, 35(1), 139-149. DOI:10.1080/15391523.2002.10782375

Wu, J. H., Tennyson, R. D., \& Hsia, T. L. (2010). A study of student satisfaction in a blended e-learning system environment. Computers \& Education, 55, 155-164. Retrieved from http://dx.doi.org/10.1016/j.compedu.2009.12.012

Zimpher, N. L., deVoss, G. G., \& Nott, D. L. (1980). A close look at university student teacher supervision. Journal of Teacher Education, 31(4), 11-15.

Young, A., \& MacPhail, A. (2014). Standing on the periphery: Cooperating teachers' perceptions and responses to the role of supervision. EuropeanPhysical Education Review (EPER), 1-16. DOI: 10.1177/1356336X14557582

Zulu, A. (2015). Role parameters within the context of the practicum triad: Teacher training perspectives from Namibia's Zambezi Region (Unpublished doctoral dissertation). University of South Africa, South Africa.

Athabasca

University

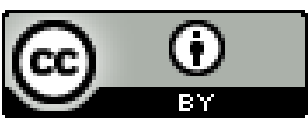

